\title{
Stream typology and dynamics of leaf processing
}

\author{
R.M. Cortes ${ }^{1}$ \\ M.A.S. Graça 2 \\ J.N. Vingada 2 \\ S. Varandas de Oliveira1
}

Keywords : leaf processing, allochthonous input, macroinvertebrates, shredders, biotypology.

Is it possible to link leaf decomposition and associated invertebrates with the typological character of an heterotrophic stream? This is an important question because it is related the spatial dynamics of the functioning low order streams, in the sense that it considers the use and interactions of allochthonous organic material along the horizontal axis of the stream. In the autumn/winter of two successive years, alder leaf breakdown rates and their nutrient variation (N,P,K) were estimated in a stream with energetically increasing dependence on POM inputs in the upstream direction. The succession of invertebrates colonizing the incubated leaves was observed and related to the characteristics of this organic substrate. Though extremely variable in time, the coefficients of decomposition revealed a spatial gradient in close association with the specific heterotrophic character of the different sites. Invertebrate trophic groups colonizing the leaves exhibited a pattern similar to their typological distribution in the stream : shredders were dominant in the upper stations and they were replaced by collectors in the lower ones. We concluded that a longitudinal pattern of decomposition of exogenous organic materials exists in streams that show a predictable typological shift along this gradient.

\section{Typologie de rivière et dynamique de la décomposition des feuilles}

Mots clés : décomposition des feuilles, détritus allochtones, macroinvertébrés, déchiqueteurs, biotypologie.

Est-il possible de relier la décomposition des feuilles et les invertébrés qui y sont associés avec les caractéristiques typologiques d'une rivière à caractère hétérotrophe ? Cela est une question importante car elle a trait à la dynamique spatiale du fonctionnement des rivières d'ordre réduit dans la mesure où elle traite de l'utilisation et des interactions de la matière organique allochtone tout au long du cours. Pendant l'automne/hiver de deux années consécutives les taux de décomposition des feuilles d'aulne et leur variation respective en nutriments (N, P, K) ont été évalués dans un cours d'eau qui dépend de façon croissante des apports de POM en direction de la source. La succession des invertébrés qui ont colonisé les feuilles en incubation a été observée et mise en relation avec les caractéristiques de ces feuilles. Les coefficients de décomposition, malgré une extrême variation temporelle, ont révélé un gradient spatial bien corrélé avec les conditions d'hétérotrophie spécifiques de chaque site. Les groupes fonctionnels d'invertébrés qui colonisent les feuilles reflètent étroitement leur répartition typologique dans la rivière : les déchiqueteurs dominants dans les stations amont sont remplacés par les collecteurs vers l'aval. Nous pouvons conclure qu'il existe, dans les rivières typologiquement structurées, une variation spatiale du mode de décomposition des matières organiques allochtones qui a un rapport avec le gradient longitudinal du système lui-même.

\section{Introduction}

It has been accepted since Minshall (1966), Iversen (1973) and Cummins (1974), that in low order streams draining forested catchments, benthic communities are highly dependent on allochthonous

1. Departamento Florestal, Universidade de Trás-os-Montes e Alto Douro, Apt. 202, 5001 Vila Real Codex, Portugal.

2. Departamento Zoologia, Universidade de Coimbra, 3049 Coimbra Codex, Portugal. inputs in varying stages of decomposition as an energy source. Most of the studies in detritus - based stream systems have been carried out in Northern Europe and America, but the literature selected by Graça (1993) suggests that in other areas the magnitude of litter fall is similar to that of the northern deciduous forests. The breakdown rates of those inputs have been associated with abiotic factors, particularly temperature, acidification, flow and water chemistry (Rounick \& Winterbourn 1983, Newbold 
et al. 1983, Burton et al. 1985, Chauvet 1988, Thompson \& Bärlocher 1989), and with biotic factors, mainly the role played by invertebrates, in association with the nutritional value of litter (see Anderson \& Sedell 1979 for a review, Taylor et al. 1989, Blair et al. 1990). A great deal of attention has also been paid to estimates and comparisons of decay rates of different leaf species for specific environmental conditions, and to the macro- and microconsumers involved in each case (Imbert \& Pozo 1989, Blair et al. 1990, Beiser et al. 1991).

Some studies were long term surveys, conducted to detect the seasonal variation of the gradual weight loss (McArthur et al. 1988, Campbell et al. 1991). In other cases, breakdown rates have been compared for streams in distinct biogeographical situations (Gazzera et al. 1993), or between headwaters and lowland rivers (Merritt \& Lawson 1992, Chauvet et al. 1993).

However, longitudinal studies of litter dynamics are relatively scarce. Some significant contributions to this subject focus specifically on particulate organic matter (POM) transport along the transversal or longitudinal profile, generally linking discharge parameters and sediment storage (Cuffney \& Wallace 1989, Potts \& Anderson 1990, Bretschko 1990). If such research is to shed some light on the amount, availability and prediction of food resources in space and time, it needs to be correlated with the spatial variation in the processing of such organic debris.

Our purpose is to analyse the decomposition of alder (Alnus glutinosa) leaves along the longitudinal gradient of a mountain heterotrophic stream and the dynamics of associated invertebrate taxa. In this way, we attempted to integrate abiotic and biotic factors involved, keeping in mind the hierarchical nature of lotic ecosystems.

Our question is whether there is a relationship between stream typology and the pattern of leaf breakdown. If that hypothesis is accepted, we intend to characterize the spatial variation of benthic organisms associated with the flow of energy, i.e. weight loss from alder leaf packs.

\section{Material and methods}

\subsection{Sites and their energetic characterization}

The work was carried out on the River Olo, which has been extensively surveyed in order to determine its biotypological characteristics (Cortes 1992). This is a high gradient stream, located in Northern Portugal, in the Alvão Natural Park, draining a mountain area of reduced human impact. The acid waters of $\mathrm{R}$. Olo have a low concentration of inorganic compounds. Five sites, from orders 3 to 5 (high to low rhithron), were selected to reflect natural variations along the river. Their main biotic and abiotic features are described in the work above mentioned, which revealed a marked longitudinal succession of invertebrate species.

Sites 1 and 2 (headwaters) are $1 \mathrm{~km}$ apart, which is also the distance between sites 3 and 4 . Distances between sites 2-3 and 4-5 are, respectively, 6.3 and $10.7 \mathrm{~km}$. The difference of altitude between the first and the last site is $850 \mathrm{~m}$.

Maximum annual values for all sites were : conductivity : $39.6{ }_{\mu}{\mathrm{S} . \mathrm{cm}^{-1}}^{-1} \mathrm{~N}-\mathrm{NO}_{3}{ }^{-}: 0.6 \mathrm{mg} . \mathrm{l}^{-1}$; $\mathrm{P}_{-} \mathrm{PO}_{4}{ }^{3-}: 0.05 \mathrm{mg} .1^{-1}, \mathrm{Cl}^{-}: 2.0 \mathrm{mg} . \mathrm{l}^{-1} ; \mathrm{SO}_{4}{ }^{2-}$ : $2.1 \mathrm{mg} . \mathrm{I}^{-1}$. There was a steady decrease of the values of these parameters as we approached site 1 (here, average conductivity was $15 \mu \mathrm{S} . \mathrm{cm}^{-1}$ ). In general, the stream is well shaded, almost exclusively by $A$. glutinosa, except in site 4, where riparian vegetation is completely absent since the banks are rocky. A rough boulder-stream bed and steep banks, together with high water velocity, are the common features at sites $1-4$, but not at site 5 , which is separated from the previous one by an impressive waterfall. Here, the river bed consists of smaller material (pebbles and gravel), and riffles alternate with pools where, in low discharge periods, there is considerable accumulation of allochthonous organic debris.

We tested the assumption that autochthonous inputs were negligible in the energetic budget of the stream. This was done by assessing the periphytic primary production in summer 1992 through : a) determination of chlorophyll $a$ and $b$ in the exposed area of the mineral components of bed substratum (this area ranged between $60.5 \mathrm{~cm}^{2}$ and $140.7 \mathrm{~cm}^{2}$ in each of the three replicates per site) ; b) determination of in situ oxygen variation in a plexiglass closed chamber ( 2 hours light $/ 2$ hours darkness with data stored each minute in a logger - multiparametric system pHOX). To convert mass of oxygen into mass of carbon, we used the coefficients presented in Wetzel \& Likens (1991). For quantifying the accumulation of terrestrial derived 
particulate organic matter, a bottom sampler was used with a $50 \mu \mathrm{m}$ mesh. Six samples of $100-250 \mathrm{~cm}^{2}$ were collected at random in each site. In the laboratory, benthic particulate organic matter (BPOM) was separated into large organic debris (LOD), coarse and fine particulate organic matter (respectively CPOM and FPOM) - categories defined in Platts et al. (1973). These determinations were accomplished in fall and winter.

\subsection{Leaf decomposition and invertebrate colonization}

Leaf decomposition was investigated in two different years : in autumn 1991 (starting middle of October) for all the five sites previously described, and in autumn 1993 (middle of October) for the same sites, except site 1. An additional period of exposure was considered in site 2, during winter 1991 (starting in the middle of December) ; this last sampling schedule was to compare leaf decomposition under high allochthonous input (autumn) to decomposition when this input is virtually over (winter). Alder leaves were carefully selected in order to collect only the ones that were just prior to abcission. Afterwards they were stored dry until needed, when they were oven dried at $60^{\circ} \mathrm{C}$ for at least $48 \mathrm{~h}$. Next, the leaves were weighed into $4.0 \mathrm{~g}$ groups, remoistened and placed in $6 \mathrm{~mm}$ mesh bags. The bags were sealed and attached to nylon ropes, which were anchored with bricks in each site. The leaf bags were used to estimate leaf breakdown rates and to observe the sequence of invertebrates colonization. Two bags were collected each time, following as much as possible a temporal geometric scale : on days $1,2,4$, $8,16,32$ and 64 . However, this schedule was slightly changed because of weather conditions : in autumn of the both years a flood displaced most of the bags before day 64, which was not considered, and in winter 1991 it was necessary to extend the exposure till day 66 because an intense flood prevented to collect the submerged material two days before. The leaves were gently washed immediately in the laboratory to remove attached sediments and the invertebrates were sorted and stored in $70 \%$ alcohol. In the first year, the organisms were identified mostly by species or genus ; in the second year, we only determined the overall biomass of the assemblage colonizing each replicate bag (the invertebrates were not preserved after sorting and, instead, were dried at $80^{\circ} \mathrm{C}$ for 2 days and weighed to the nearest $0.1 \mathrm{mg}$ ). Leaves were used for ash free dry weight (AFDW) measurements (at $600^{\circ} \mathrm{C}$ to constant weight) and for determination of total $\mathrm{N}, \mathrm{P}$ and $\mathrm{K}$ contents. These nutrient analysis used a diggestion with sulphuric acid and determination of $\mathrm{N}$ was done by the Berthelot method, of $\mathrm{P}$ by the molibdate - ascorbic acid method and $\mathrm{K}$ by flame photometry - in Novozamski et al. (1983).

The use of leaf bags has been criticized because it reduces water exchange and abrasion, and excludes some invertebrates (Boulton \& Boon 1990). However, the strong flow rate during the winter months did not allow the use of unenclosed packs.

\subsection{Statistical analysis}

Processing rates were obtained by fitting weight loss data to the exponential model $\mathrm{W}_{\mathrm{t}}=\mathrm{W}_{\mathrm{o}} \mathrm{e}^{-\mathrm{kt}}$, where $\mathrm{k}$ is the processing coefficient and $\mathrm{W}_{\mathrm{t}}$ is the amount of leaf material remaining after time $t$ from the initial amount $W_{0}$.

Macroinvertebrate taxa were ranked following dispersion criteria based on a matrix of correlations and considering the elimination of the residuals. The objective was to detect the most important variables (species), the ones that discriminate more efficiently between sites and colonization periods. A fuzzy clustering was used for classifying sites and sampling data into a reduced number of clusters, to separate only the most distinct groups. In fact, this method displays the cluster membership weights, so we may judge which were the highest separated points from the ones where there was stronger uncertainty. Programs RANSQ and FCM of the package SYN-TAX (version IV) - Podani (1990) - were used, for ranking taxa and clustering sites, respectively.

Finally, we ordinated taxa and sites through Detrended Correspondence Analysis (DCA), using the algorithm of CANOCO (Ter Braak 1987). This technique arranges data in order to avoid the compression of the ordination axes and its quadratic distortion, so that the axes reproduce more correctly the environmental gradients than methods like Principal Components Analysis or Reciprocal Averaging (Hill 1979). 


\section{Results}

\subsection{Autochthonous/Allochthonous organic matter gradients}

The autochtonous primary productivity of the stream, based on the changes of dissolved oxygen was low. In site 2, net photosynthesis was $125.0 \mathrm{mg}$ C. $\mathrm{m}^{-2} \cdot \mathrm{h}^{-1}$; in site 5 it was $218.8 \mathrm{mg} \mathrm{C} \cdot \mathrm{m}^{-2} \cdot \mathrm{h}^{-1}$. However, these values were obtained in July/August and did not represent mean productivity for the entire year, which is presumably much lower. Benthic chlorophyll $a$ and $b$, for the same period, were also low (Table 1).

Table 1. Benthic chlorophyll a and $\mathrm{b}\left(\mu \mathrm{g} / \mathrm{cm}^{2}\right)$ at 4 sites along River Olo, in July/August 1991.

Tableau 1. Chlorophylle benthique a et b $\left(\mu \mathrm{g} / \mathrm{cm}^{2}\right)$ dans 4 stations réparties le long de la rivière Olo, en Juillet/Août 1991.

\begin{tabular}{ccc}
\hline Sites & Chlorophyll a & Chlorophyll $b$ \\
\hline 1 & 1.32 & 0.40 \\
2 & 1.97 & 0.98 \\
3 & 2.33 & 0.78 \\
4 & 2.97 & 0.87 \\
\hline
\end{tabular}

Table 2 shows the quantitative values of BPOM fractions, obtained for two sampling periods. They reflect the variations in space and time of input and retention of particulate organic matter. Higher accumulation of POM (mainly CPOM) occurred in the upper reaches, and is inversely related to primary production.

\subsection{Spatial pattern of leaf decay}

Alder leaves decayed at very distinct rates, depending on temporal and spatial factors (Table 3). These results also show that the model $\mathrm{W}_{\mathrm{t}}=\mathrm{a} \mathrm{W}_{\mathrm{o}} \mathrm{e}^{-\mathrm{kt}}$ was found to be more appropriate than the general expression without the constant : it corrects the effect of silting on leaves (aspect not completely corrected by cleaning), improving, consequently, the correlation coefficients. Higher processing rates occurred in the upper reaches (sites 1 and 2) especially when compared to site 5 . The marked spatial pattern overcame the effect of increasing water temperature in the downstream direction, which gives
Table 2. Standing crop of the three considered benthic particulate organic matter franctions $\left(\mathrm{mg} / \mathrm{cm}^{2}\right)$ for two periods at the 5 sites along R. Olo. Samples were not collected at site $1-2^{\text {nd }}$ period.

Tableau 2. Accumulation des trois fractions considérées de matière organique particulée benthique $\left(\mathrm{mg} / \mathrm{cm}^{2}\right)$, pour deux périodes, dans les 5 stations réparties le long de la rivière Olo. Absences de données pour la station 1 - $2^{e}$ période.

\begin{tabular}{crrrrrr}
\hline Sites & \multicolumn{3}{c}{ November 91} & \multicolumn{3}{c}{ March 92 } \\
\hline & LOD CPOM & FPOM & \multicolumn{2}{c}{ LOD CPOM } & FPOM \\
1 & 0.765 & 9.348 & 14.071 & - & - & - \\
2 & 0.683 & 33.660 & 10.208 & 0.748 & 36.430 & 3.851 \\
3 & 0.226 & 0.433 & 0.588 & 0.486 & 0.538 & 0.746 \\
4 & 0.055 & 1.205 & 1.384 & 0.819 & 0.686 & 1.123 \\
5 & 3.473 & 1.004 & 1.962 & 0.061 & 0.643 & 1.390 \\
\hline
\end{tabular}

a special relevance to other physical and biotic factors involved. Practically no differences were observed for $\mathrm{k}$ values between sites 3 and 4 (second year), in spite of striking contrast in riparian cover.

Fig. 1 represents the temporal changes of $N, P$ and $K$ content in the alder leaves for the different sites. Each nutrient reflects a specific pattern : while $\mathrm{N}$ shows a steady increase during the first 2 weeks, $P$ reflects an intense leaching during 1-2 days. Leaching last till day 4 when $K$ is considered. In the particular case of $P$, in spite of the different trends exhibited for the two periods, it seems that immobilisation of this nutrient may proceed after day 32 , when retention was completed for $\mathrm{N}$.

\subsection{Macroinvertebrate assemblages and leaf breakdown}

Multivariate analysis was used to group samples and taxa colonizing the leaf packs from the different sites and collecting times during the first year.

A fuzzy partition was established, but limited to 3 clusters to reduce dimension and to avoid outlier effects, where the coefficient of fuzziness was defined as 1.5. Variables (species values) were first log transformed. Table 4 presents only the samples with higher membership weights, the ones with the strongest affinity to each cluster. Coefficient of overall separation was 22.801 , with a normalized partition entropy of 0.735 . The pairwise separation coefficients were $1.523,0.980$ and 0.547 between, respectively, clusters 1-2, 1-3 and 2-3. Partition efficiency 
Table 3. Processing coefficients $k$ of alder leaves and fitted values $\left({ }^{* *} P<0.01,{ }^{*} P<0.05\right)$ after the exponential models (1 $1^{\text {st }}$ year) not available.

a) $W=a W_{0}^{-k t}$ and b) $W=W_{0}^{-k t}$. Data on day 32 at site 3

Tableau 3. Valeurs du coefficient de décomposition $\mathrm{k}$ pour les feuilles d'aulne et valeurs ajustées $\left({ }^{* *} \mathrm{P}<0.01,{ }^{*} \mathrm{P}<0.05\right)$ d'après les modèles exponentiels $\left.\mathrm{a}\right) \mathrm{W}=\mathrm{a} \mathrm{W}_{\mathrm{o}}{ }^{-k t}$ et $\left.\mathrm{b}\right) \mathrm{W}=\mathrm{W}_{0}{ }^{-k t}$. Les données du $32^{e}$ jour de la station 3 (1 $1^{\text {ere }}$ année) ne sont pas disponibles.

\begin{tabular}{ccccl}
\hline SITES & $\mathrm{k}$ a) & $\mathrm{r}$ & $\mathrm{k} \mathrm{b}$ ) & $\mathrm{r}$ \\
\hline 1st year & & & & \\
1 1 & 0.0098 & $0.993^{* *}$ & 0.0148 & $0.918^{* *}$ \\
2 (1st per.) & 0.0127 & $0.968^{* *}$ & 0.0179 & $0.927^{* *}$ \\
2 (2nd per.) & 0.0092 & $0.952^{* *}$ & 0.0141 & $0.902^{*}$ \\
3 & 0.0058 & $0.887^{*}$ & 0.0130 & 0.473 \\
4 & 0.0088 & $0.990^{* *}$ & 0.0143 & $0.865^{*}$ \\
5 & 0.0049 & $0.965^{*}$ & 0.0083 & $0.946^{* *}$ \\
2nd year & & & & \\
2 & 0.0054 & $0.952^{* *}$ & 0.0090 & 0.622 \\
3 & 0.0051 & $0.925^{* *}$ & 0.0088 & 0.519 \\
4 & 0.0052 & $0.923^{* *}$ & 0.0089 & $0.716^{*}$ \\
5 & 0.0014 & $0.715^{*}$ & 0.0050 & 0.542 \\
\hline
\end{tabular}

Table 4. Fuzzy partition of invertebrate samples (site-collecting time). Samples are ranked by order of affinity in each cluster : cluster 1 contains samples with weights $>0.90$ and clusters 2 and 3 the ones with weights $>0.70$ (membership weights range from 0 to 1 ).

Tableau 4. Codage flou des échantillons d'invertébrés (stationdate de récolte). Les échantillons sont ordonnés selon leur affinité dans chaque groupe : dans le groupe 1 sont compris les échantillons de poids $>0.90$ et dans les groupes 2 et 3 les échantillons de poids $>0.70$ (amplitude de-variation de poids : 0-1).

\begin{tabular}{|c|c|c|}
\hline Cluster 1 & Cluster 2 & Cluster 3 \\
\hline 5-day 4 & $2\left(2^{\text {nd }}\right)$-day 32 & 2-day 2 \\
\hline 5-day 1 & & 3-day 16 \\
\hline 4-day 4 & $2\left(2^{\text {nd }}\right)$-day 16 & 3-day 8 \\
\hline 5-day 2 & 1-day 8 & 2-day 4 \\
\hline 5-day 8 & 2 (2nd)-day 8 & 3-day 4 \\
\hline 4-day 2 & 1-day 32 & \\
\hline 4-day 1 & & \\
\hline
\end{tabular}

was considerabl higher because the coefficient of separation is not far from the number of objects, and coefficients between clusters are low, and so is entropy (Podani 1990). Increasing number of clusters generated significantly less clear partitions. The clearest feature was the separation of samples from the lower reaches (sites 5 and 4 , in cluster 1). A temporal separation was also obvious, mainly of samples from the second period (cluster 2) and, additionally, the grouping of samples with a shorter time of incubation in the river (cluster 3).

DCA was a powerful tool to interpret the complexity of the invertebrate species succession colonizing the alder leaf bags. The figure 2 is the plot of samples against the first two axes of the ordination (eigenvalue of $\mathrm{X} 1: 0.355$; eigenvalue of $\mathrm{X} 2$ : $0.269)$, which results of a $\ln (x+1)$ transformation of species values, with the downweighting of rare species (resulting in 37 active samples and 75 active species). This figure reveals the spatial and temporal gradients. Sites are discriminated along axis 1, following the longitudinal gradient of the stream, particularly site 5 was located at the end of this axis, which was also in fair agreement with the fuzzy classification. From the same diagram, we may conclude at a chain of interactions of the organisms processing POM, side to side with stream typology. Furthermore, samples belonging to the second colonization period (winter) appear individualized on axis 1 , but also along axis 2 , indicating rather distinct invertebrate communities between the two periods. Samples from sites 3 and 4, characterized by distinct POM input, present similar faunistic composition. This observation stresses the importance of POM transport in fast flowing streams (Table 2) already 
showed that BPOM load was similar in both sites), which creates a typological energetic relationship of the organisms acting in the processing of organic matter.

The spatial character of invertebrate taxa colonizing the alder decaying leaves was enhanced by DCA ordination (Fig. 3). Their distribution can be related to the functional categories, linked to the POM fractions available along the horizontal gradient of the stream. The upstream reaches are characterized, excluding rare species, by the presence of different Ecdyonurus spp. and Beraea sp., which appear in the first period, followed later on (winter) by the dominance of shredder-detritivores, like Leuctra spp., Potamophylax cingulatus Stephens and Sericostoma vittatum Rambur (trophic categories after various literature : e.g. Merritt \& Cummins 1984, Iversen 1988). Other taxa present in winter included some engulfers (predators) - Siphonoperla torrentium Pictet, Polycelis felina Dalyell, Rhyacophila adjuncta Mclachlan and Isoperla sp., and a few collector-gatherers like Habrophlebia fusca Curtis. The most relevant taxa colonizing leaves in the lower reach (site 5) were mainly collector-gatherers, represented by Centroptilum pennulatum Eaton, Ephemerella mesoleuca Brauer, Chinonomini spp., and the collector-filter feeders, e.g. Hydropsyche pellucidula Curtis.

Taxa were ranked using the program RANSQ and results are presented in Table 5. This procedure explains $88 \%$ of the total variation. Higher importance was given mainly to species appearing in the last stages of colonization, which means that these species are more correlated, between them or with other taxa, thus providing greater contribution to the global variance. We conclude that there is an increasing specialization of the fauna as leaf incubation proceeds, together with a trend in increasing biotic interactions. By contrast, species appearing in the first phase of leaf processing present a very low level of interaction between them. Most of these taxa are not included in Table 5, because their contribution to the variance is much lower as their appearance is probably casual.

Finally, we analysed the total biomass dynamics of the macroinvertebrates appearing in each stage of the colonization sequence during the second year. The figure 4 clearly shows that there is no relationship between the overall biomass of invertebrates
N
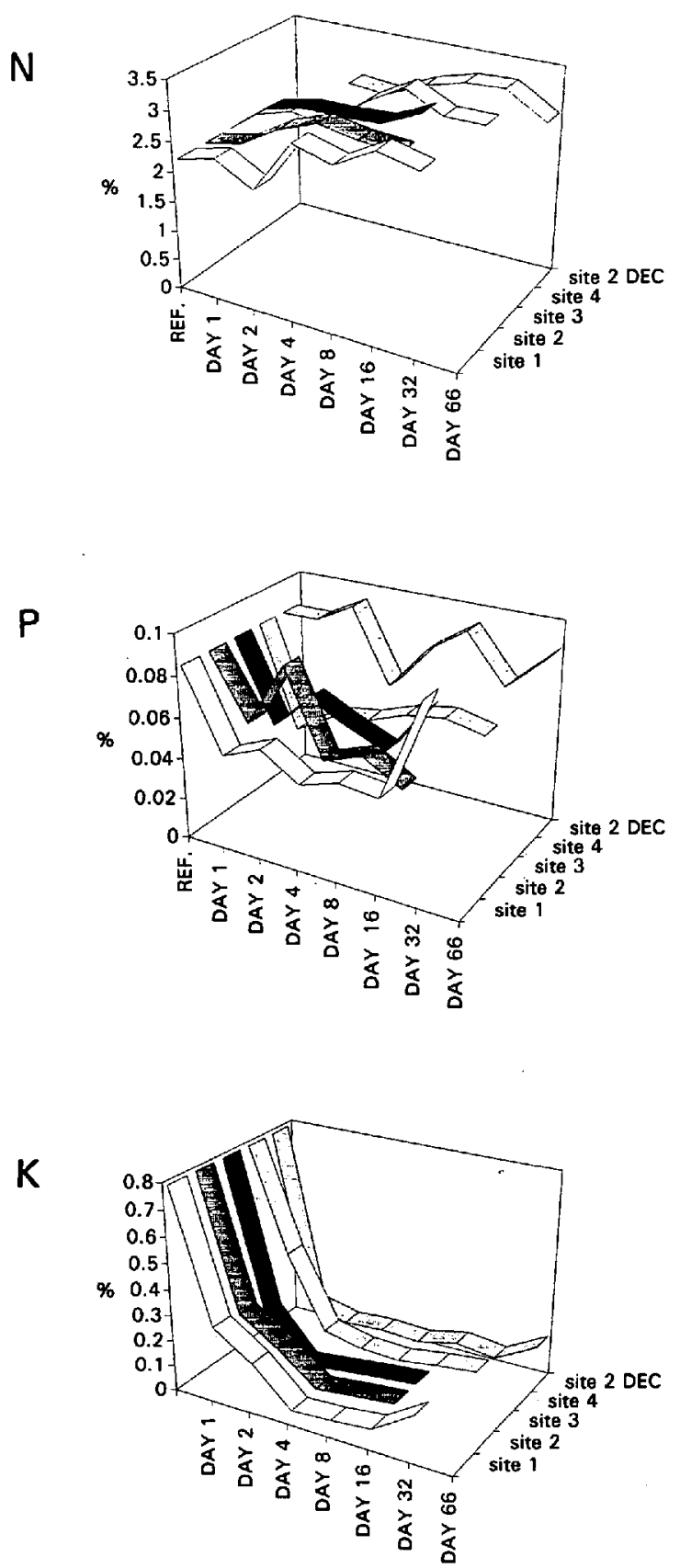

Fig. 1. Concentrations of N, P and $\mathrm{K}$ in the alder leaves along the longitudinal gradient of $R$. Olo during the first year (values in $\%$ of dry weight). A second incubation period starting in December was considered in site 2 . Site 5 was excluded because of lack of data.

Fig. 1. Variation des concentrations de $\mathbf{N}, \mathbf{P}$ et $\mathbf{K}$ dans les feuilles d'aulne le long de la rivière Olo pendant la $1^{\text {ere }}$ année (les valeurs sont exprimées en $\%$ du poids sec). Pour la station 2 il a été considéré une deuxième période d'incubation au début du mois de décembre. La station 5 a été écartée (données insuffisantes). 


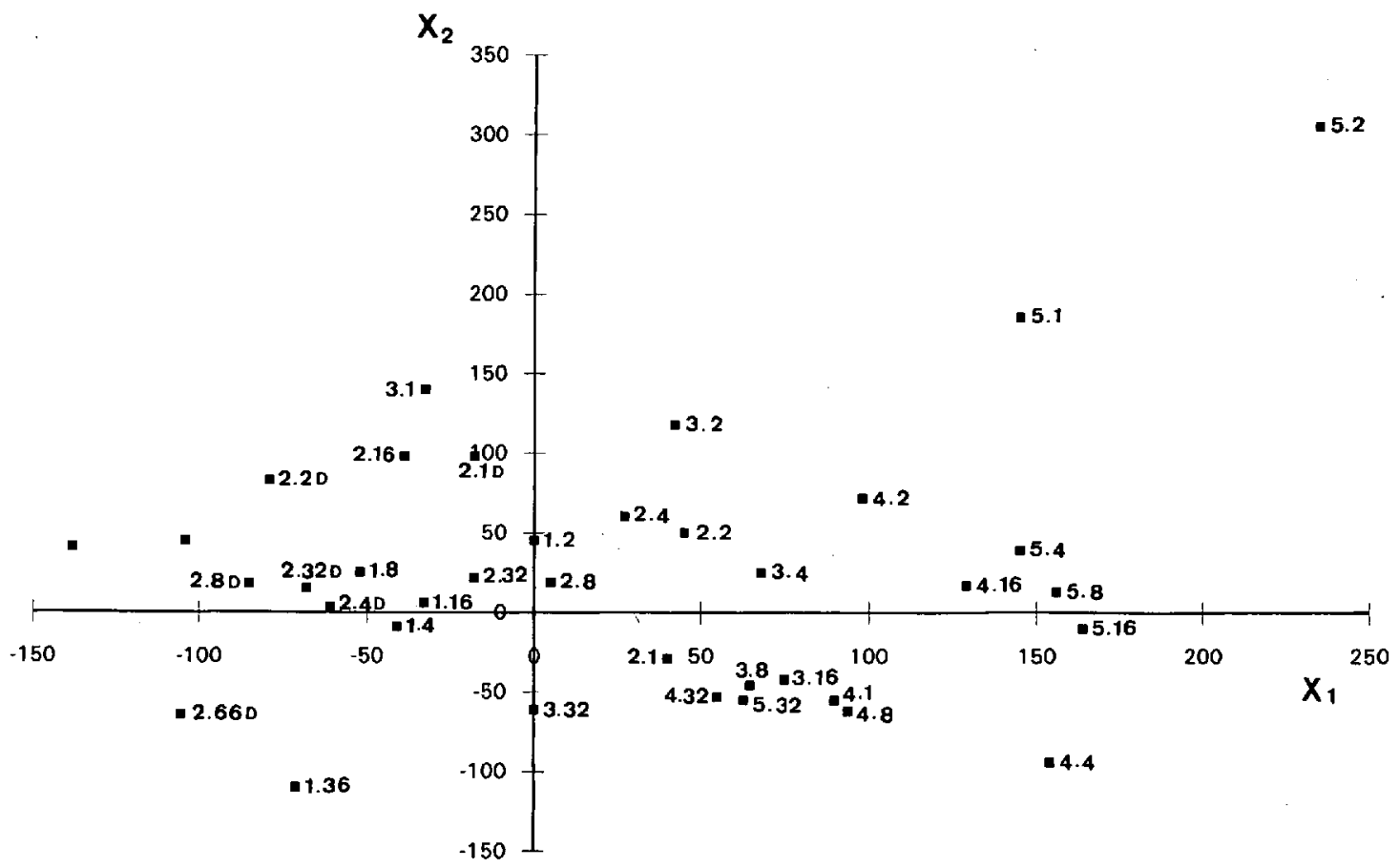

Fig. 2. Diagram of invertebrate samples (site versus time) against the first two axes of DCA ordination : e.g. $266 \mathrm{D}$ means incubated leaves collected at site 2 after 66 days of exposure, starting in December (2nd period).

Fig. 2. Représentation graphique des échantillons d'invertébrés (station versus temps) selon les deux premiers axes de l'ordination DCA : ex. 2.66 D correspond aux feuilles obtenues dans la station 2 après 66 jours d'incubation, débutant en décembre de la $2^{\mathrm{e}}$ période.

and $k$ values - e.g. theoretically site 3 should have the highest coefficient according to its biomass. However, a linear model with a positive slope can be fitted between biomass and time in all circumstances (Table 6), but this inference is only allowed for the first month of colonization.

\section{Discussion}

Low order streams are considered very retentive, particularly the ones draining forested catchments (e.g. Anderson \& Sedell 1979). The benthic fauna of these reaches has evolved to gouge, scrape and shred leaves and wood, and it is efficient in processing coarse material (Fisher \& Likens 1973), which, to a large extent, accumulates because of the roughness of the river bed, but also because of the station of bank to water area (Chergui \& Pattée 1993). Cummins et al. $(1984,1989)$ point to the strong relationship between riparian plant cover and the leaf that becomes trapped. In addition, as predicted by the « river continuum » (Vannote et al. 1980), CPOM decreases downstream whereas the importance of system primary production, as judged by chlorophyll measurements, seems to increase (the upper reach of R. Olo is typically olitrophic according to Jorgensen 1980) - see Tables 1 and 2 . In these heterotrophic aquatic systems the organic materials entering the stream are used only in a small amount by the consumers, but they are exported downstream, also because metabolic activity of CPOM is considerably lower than of FPOM (Naiman \& Sedell 1980).

However, the small differences of POM accumulation between the two sampling periods (Table 2) suggest that the input of exogenous organic matter was prolonged through spring and/or that its 


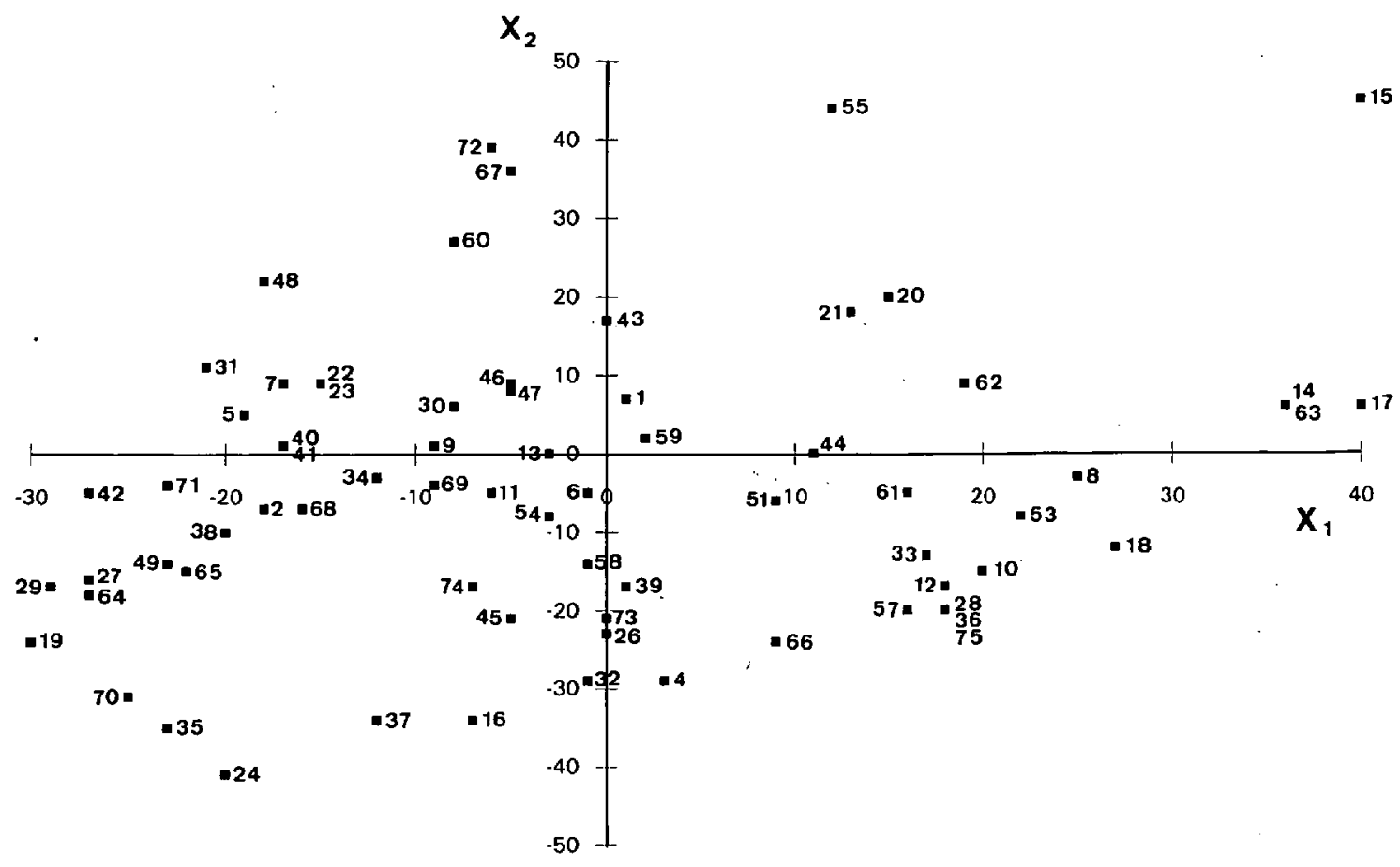

Fig. 3. DCA ordination of species. Numbers in the figure correspond to the following taxa :

Fig. 3. Les chiffres figurés sur la DCA correspondent aux taxa suivants :

\author{
1 - Agabus \\ 2 - Amphinemura triangularis \\ 3 - Ancylus fluviatilis \\ 4 - Atheryx \\ 5 - Baetis gr. alpinus \\ 6 - Baetis rhodani \\ 7 - Beraea \\ 8 - Boyeria irene \\ 9 - Bragasellus cortesi \\ 10 - Caenis luctuosa \\ 11 - Callyarcis humilis \\ 12 - Calopteryx virgo \\ 13 - Capnioneura libera \\ 14 - Centroptilum lutcolum \\ 15 - Centroptilum penulatum \\ 16 - Ceratopogonidae \\ 17 - Chironomidae (pupae) \\ 18 - Chironomini \\ 19 - Corixinae \\ 20 - Corynoneura \\ 21 - Dixella \\ 22 - Ecdyonurus \\ 23 - Ecdyonurus dispar \\ 24 - Ecdyonurus forcipula \\ 25 - Elmis
}

26 - Empididae

27 - Ephemerella

28 - Ephemerella mesoleuca

29 - Esolus parallelepipedus

30 - Eusimulium

31 - Habrophlebia fusca

32 - Helodes

33 - Hydracarina

34 - Hydrochus

35 - Hydrocyphon deflexicolis

36 - Hydropsyche pellucidula

37 - Hydropsyche siltalai

38 - Isoperla

39 - Lepidostoma hirtum

40 - Leuctra alosi

41 - Leuctra fusca

42 - Leuctra hippopus

43 - Leuctra inermis

44 - Leuctra

45 - Leuctra leptogaster

46 - Leuctra maroccana

47 - Leuctra stupeningi

48 - Limnephilidae

49 - Limoniidae

50 - Lumbricidae
51 - Lumbriculidae

52 - Micrasema

53 - Naididae

54 - Nemoura

55 - Notonecta

56 - Oecetis testacea

57 - Onychogomphus uncatus

58 - Orectochillus villosus

59 - Orthocladiinae

60 - Oulimnius

61 - Oxyethira archaica

62 - Phagocata vitta

63 - Plectrocnemia inflata

64 - Polycelis felina

65 - Potamophylax cingulatus

66 - Protonemura meyeri

67 - Protonemura pyrenaica

68 - Rhyacophila adjuncta

69 - Rhyacophila

70 - Sericostoma vittatum

71 - Siphonoperla torrentium

72 - Sminthuridae

73 - Tanypodinae

74 - Tanytarsini

75 - Tipula 


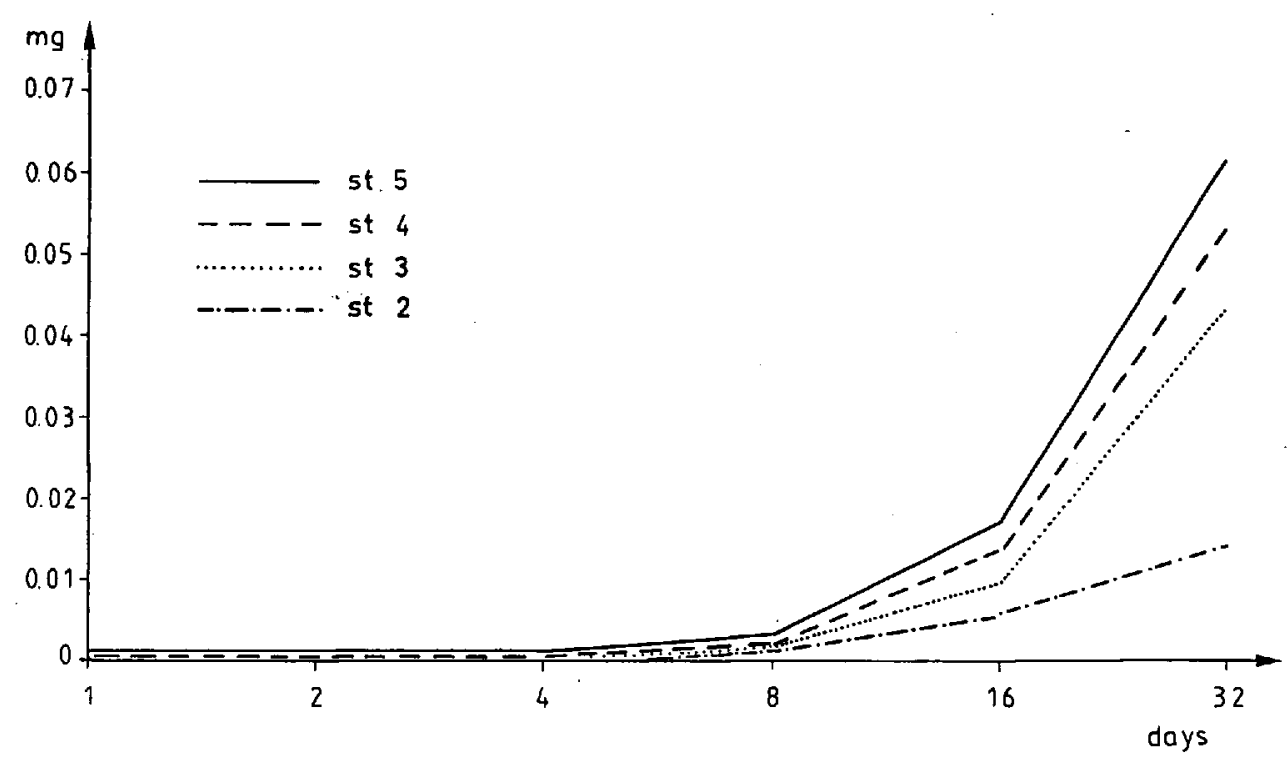

Fig. 4. Biomass dynamics of invertebrates colonizing the alder leaves at four sites during the 2nd year of study. Time is in log scale. Ordinates represent mg invertebrates (dry weight) per bag.

Fig. 4. Dynamique de l'évolution de la biomasse des invertébrés qui colonisent les feuilles d'aulne dans quatre stations au cours de la $2^{c}$ année. Le temps est représenté dans une échelle logarithmique et les ordonnées représentent le poids sec d'invertébrés en $\mathrm{mg}$ par sac.

residence time in the channel was long. The evidence that the energy supplied to the stream was rather constant during a considerable period also emerged from the type of material on the river bed : alder leaves dominated in the first period, but were later replaced by oak leaves.

These considerations certainly agree and contribute largely to characterize the stream functioning over the longitudinal profile of $\mathbf{R}$. Olo : a) $\mathbf{k}$ values decrease progressively with stream order ; b) the flux of transported organic matter buffers differences in litter accumulation between stretches with very dissimilar riparian cover, this is, with distinct POM inputs (e.g. stations 3 and 4) ; c) there is a shift of the functional feeding groups over the course of the river, particularly in a tendency towards a higher number of collectors (gatherers and filter feeders) in the downstream direction (group that integrates most of the species characteristic of site 5 - see Fig. 3).

This spatial pattern was not evident in other high gradient streams. For instance, Pozo (1993) studying the breakdown of alder leaves along the River Agüera, another stream of the Iberian Peninsula, did not find consistent spatial differences in the decay rate. However, we must consider the influence of the distinct physico-chemical features along the length of this stream, related with the geological heterogeneity of the catchment. Cortes et al. (1994) had already reported very distinct processing rates in situations of marked variation of water chemistry. Minshall et al. (1992) concluded that downstream trends in benthic and transported organic matter and system metabolism are generally predictable, but detected many differences in the expression of those trends which were considered to be due to specific environmental conditions. All types of disturbances (natural or anthropogenic ones) certainly also cause local modifications in the processing of POM. For instance, Delong \& Brusven (1993) found that there were no conclusive differences in the decomposition of leaf packs of alder along the gradient of an agricultural impacted stream because of the constant low biomass of stored benthic organic matter.

The present study also found that breakdown in a local or longitudinal perspective was highly variable in time. This is largely a consequence of the 
Table 5. Taxa rank for the first 20 species using programme RANSQ. Taxa are ranked according to their relative contribution to overall variation.

Tableau 5. Classement pour les 20 premières espèces obtenues avec le programme RANSQ. Les taxa sont ordonnés d'après leur contribution relative à la variation globale.

\begin{tabular}{clccc}
\hline Rank & \multicolumn{1}{c}{ Variable (taxa) } & $\begin{array}{c}\text { Specific } \\
\text { distance }\end{array}$ & $\begin{array}{c}\text { Relative } \\
\text { importance } \\
\%\end{array}$ & $\begin{array}{c}\text { Cumulative } \\
\text { imponance } \\
\%\end{array}$ \\
\hline 1 & Ceratopogonidae & 10.8 & 13.5 & 13.5 \\
2 & Sericostoma vittatum/pyrenaicum & 8.9 & 11.2 & 24.7 \\
3 & Callyarcis humilis & 5.9 & 7.4 & 32.1 \\
4 & Lepidostoma hirtum & 5.2 & 6.4 & 38.6 \\
5 & Elmis & 4.5 & 5.6 & 44.1 \\
6 & Siphonoperla torrentium & 3.7 & 4.7 & 48.8 \\
7 & Polycelis felina & 3.6 & 4.5 & 53.3 \\
8 & Hydracarina & 3.1 & 3.8 & 57.1 \\
9 & Plectrocnemia inflata/laetabilis & 3.0 & 3.7 & 60.8 \\
10 & Potamophylax cingulatus/latipennis & 2.8 & 3.5 & 64.3 \\
11 & Orthocladiinae & 2.6 & 3.3 & 67.6 \\
12 & Psychodidae & 2.3 & 2.9 & 70.6 \\
13 & Bragasellis cortesi & 2.3 & 2.9 & 73.4 \\
14 & Limnephilidae juveniles & 2.2 & 2.8 & 76.2 \\
15 & Naididae & 2.0 & 2.4 & 78.7 \\
16 & Isoperla & 1.8 & 2.2 & 81.0 \\
17 & Leuctra inermis & 1.6 & 2.0 & 83.0 \\
18 & Boyeria irene & 1.4 & 1.8 & 84.8 \\
19 & Plactycnemis latipes/acutipennis & 1.3 & 1.6 & 86.4 \\
20 & Corynoneura & 1.3 & 1.6 & 88.0 \\
\hline
\end{tabular}

Table 6. Coefficients of linear regressions between total invertebrate biomass colonizing the alder leaves and time, for the second year of study. All coefficients $r$ are significant at $P$ $<0.01$.

Tableau 6. Coefficients de régression entre la biomasse globale des invertébrés qui colonisent les feuilles d'aulne et le temps, pour la deuxième année d'étude. Tous les coefficients sont significatifs à $\mathrm{P}<0.01$.

\begin{tabular}{cc}
\hline & $r$ \\
\hline site 2 & 0.982 \\
site 3 & 0.933 \\
site 4 & 0.983 \\
site 5 & 0.992 \\
\hline
\end{tabular}

temporal dynamics of benthic and transported POM. These fluctuations are, in part, dependent on the physical conditions that increase or decrease the retention capacity of the stream channel (Bretschko 1990). But the significant changes of the physical attributes of the habitat, related with the irregular discharge regime, also directly influence the biological activity : in these circumstances, opportunistic populations dominate (Statzner 1987, Cortes 1992), making any trend concerning POM processing less predictable. Gessner \& Dobson (1993) explained the differences in density of invertebrates colonizing leaf litter (inducing different decay rates) on the basis of the relative abundance of 
naturally - occurring leaf litter in the stream : leaf packs are a more attractive resource in an environment temporaly devoid of CPOM.

Caution is then necessary when $\mathrm{k}$ values are compared, because they change in association with system variability and also with the life cycle of benthic organisms. As an example of the latter aspect, Rounick \& Winterbourn (1983) showed that a single Trichoptera species could be responsible for most leaf weight loss.

The mentioned immobilisation of the most limiting nutrients in the decomposition process (Fig. 1) is similar to the one described by Chauvet (1988) and Escudero et al. (1991). The first author considers that a part of the $\mathrm{N}$ is unavailable because it corresponds to microbial exoenzymes, more or less linked to microbial compounds of foliar origin and very resistent to decomposition. However, as pointed out by Pozo (1993), an increase in $N$ and $P$ may not always imply net gains : higher concentrations can be due to the fact that carbon disappears faster than those nutrients. Gessner \& Chauvet (1994) did not find clear correlations between these nutrients neither with fungal activity, nor with breakdown rate of detrital particles. These authors suggest that nutrient control of the leaf breakdown is difficult to assess because the constant flow of water across the substratum replenishes nutrient resources continuously.

An important question still remains. What is the relative contribution of benthic communities (special shredders) and of the physical parameters to the mineralisation of the organic matter entering the stream ? Fisher \& Likens (1973) stressed the importance of current, because it acts as an energy subsidy by physically breaking down POM and dispersing materials. Many authors (Hassage \& Harrel 1986, Chergui \& Pattée 1988) reported the direct influence of fast flowing water on higher decay rates because of mechanical abrasion, effect more important on a longer time scale. Another point of view is expressed by McGeorge et al. (1991), for whom increasing temperature in the downstream direction could induce higher decomposition rate. This opinion is confirmed by Minshall et al. (1983) and Delong \& Brusven (1993), because temperature regulates metabolic activity of the microbial and invertebrate detritivores, thus influencing decomposition. In fact, on the second year of study, average water temperature was lower $\left(\simeq 3^{\circ} \mathrm{C}\right)$, probably slowing down decomposition. It is difficult to separate the role of biotic or abiotic aspects, namely the ability of the stream detritivore community to process terrestrially-derived organic matter and, probably, only studies at the habitat level could allow the hierarchisation of the variables involved. Anyway, invertebrates were found colonizing leaves as early as one day after submersion. Excluding Collembola, $85 \%$ of them were shredders, suggesting that most of the individuals belonging to this group did not require pre-conditioned leaves. Gessner $\&$ Schwoerbel (1989) and Beiser et al. (1991) had already observed the quick time of colonization by most of the shredders (whatever the leaf species), and concluded that conditioning may not be a necessary prerequisite for attracting shredding detritivores.

Notwithstanding, as we showed, macroinvertebrate biomass is not necessarily related to decomposition rate, even if it is directly related with the time of permanence in the water (Fig. 4, Table 6). The constant rise of $\mathrm{N}$ levels in the leaves may explain this growing preference of the colonizers. This inconsistent relationship between biomass or density of invertebrates and detritus was as well mentioned (Corkum 1992, Richardson 1992, Chauvet et al. 1993). It is possible that, in the later stages of decomposition, this linkage becomes more apparent (assemblages of incubated leaves seemed more specific after longer periods - Table 5). This lack of correlation is explained by Gazzera et al. (1993) by three hypothesis : a) many organisms captured in the leaf bags only seek shelter and, consequently, do not interfer directly in the decomposition ; b) feeding occurs at greater rates on the higher quality leaves ; c) shredder biomass is maximized at the time of greatest availability of litter in the stream.

As an epilogue, our results suggest that in undisturbed, typologically structured lotic ecosystems, like River Olo, where the communities are more physically than biologically controlled (see Cortes 1992), the processes involved in the breakdown of allochthonous organic material follow a definite pattern along the longitudinal gradient.

\section{References}

Anderson N.H. \& Sedell J.R. 1979. - Detritus processing by macroinvertebrates in stream ecosystems. Ann. Rev. Entomol., 24 : 351-377. 
Beiser M.C., Teresa S. \& Aumen N.G. 1991. - Macroinvertebrate trophic composition and processing of four leaf species in a Mississipi stream. J. Freshwat. Ecol., $6: 23-33$.

Blair J.M., Parmelee R.W. \& Beare M.H. 1990. - Decay rates, nitrogen fluxes and decomposer communities of mixed species foliar litter. Ecology, 71 : 1976-1981.

Boulton A.J. \& Boon P.I. 1990. - A review of methodology used to measure leaf litter decomposition in lotic environments : time to turn over an old leaf ? Aust. J. Mar. Freshwater Res., $42: 1-43$.

Bretschko G. 1990. - The dynamic aspect of coarse particulate organic matter (CPOM) on the sediment surface of a second order stream free of debris dams (RITRODAT-LUNZ study area). Hydrobiologia, $203:$ 15-28.

Burton T.M., Stanford R.M. et Allan J.W. 1985. - Acidification effects on stream biota and organic matter processing. Can J. Fish. Aquat. Sci., 42 : 538.

Campbell I.C., Cummins K.W. \& James K.R. 1991. - A preliminary investigation of seasonal differences in leaf decomposition in Australia streams. Verh. internat. Ver. Limnol., 24 : 2071-2075.

Chauvet E. 1988. - Influence of the environment on willow leaf litter decomposition in the alluvial corridor of the Garonne. Arch. Hydrobiol., 112 : 688.

Chauvet E., Giani N. \& Gessner M.O. 1993. - Breakdown and invertebrate colonization of leaf litter in two contrasting streams : significance of oligochaetes in a large river. Can. J. Fish. Aquat. Sci., 50 : 488-495.

Chergui H. \& Pattée E. 1988. - The effect of water current on the decomposition of dead leaves and needles. Verh. internat. Ver. Limnol., 23 : 1294-1298.

Corkum L.D. 1992. - Relationships between density of macroinvertebrates and detritus in rivers. Arch. Hydrobiol., 125 : 149-166.

Cortes R.M.V. 1992. - Seasonal pattern of benthic communities along the longitudinal axis of river systems and the influence of abiotic factors on the spatial structure of these communities. Arch. Hydrobiol., $126: 85-103$.

Cortes R.M.V., Graça M.A. \& Monzón A. - Replacement of alder by eucalypt along two streams with different chemical composition : Changes of the energy input and consequences to system functioning. Verh. internat. Ver. Limnol., 25 : 1697-1702.

Cuffney T.F. \& Wallace J.B. 1989. - Discharge-export relationships in headwater streams : the influence of invertebrate manipulation and drought. J.N. Am. Benthol. Soc., $8: 331-341$.

Cummins K.W. 1974. - Structure and function of stream ecosystems. Bio Science, $24: 631-641$.

Cummins K.W., Minshall G.W., Seddel J.R., Cushing C.E. \& Peterson R.C. 1984. - Stream ecosystem theory. Verh. internat. Ver. Limnol., 22 : 1818-1827.

Cummins K.W., Wilzbach M.A., Gates D.M., Pery J.B. \& Taliaferro W.B. 1989. - Shredders and riparian vegetation. Bio Science, 1 : 24-30.

Delong M. \& Brusven M.A. 1993. - Storage and decomposition of particulate organic matter along the longitudinal gradient of an agriculturally-impacted stream. Hydrobiologia, $262: 77-88$.

Escudero A., Sanz S., Arco J.M. \& del Garrido M.V. 1991 . Leaf litter decomposition in a mountain stream. Verh. internat. Ver. Limnol, 24 : 1987-1993.
Fisher G.G. \& Likens G.E. 1973. - Energy flow in Bear Brook, New Hampshire : an alternative approach to stream metabolism. Ecol. Monogr., 43 : 421-439.

Gazzera S., Cummins K.W. \& Salmoiraghi G. 1993. - Elm and maple processing rates : comparisons between and within streams. Annls. Limnol., $29: 189-202$.

Gessner M.O. \& Schwoerbel J. 1989. - Leaching kinetics of leaf litter with implications for the current concept of leaf processing in streams. Arch. Hydrobiol., 115 : 81-90.

Gessner M.O. \& Dobson M. 1993. - Colonisation of fresh and dried leaf litter by lotic macroinvertebrates. Arch. Hydrobiol:, 127 : 141-149.

Gessner M.O. \& Chauvet F. 1994. - Importance of stream microfungi in controlling breakdown rates of leaf litter. Ecology, $75 \div 1807-1817$.

Graça M.A.S. 1993. - Patterns and processes in detritus-based stream systems. Limnologica, 23 : 107-114.

Hassage R.L. \& Harrel R.C. 1986. - Allochtonous leaves as a substrate for macrobenthos. Freshwat. Ecol., $3: 453-466$.

Hill M.O. 1979. - DECORANA - A FORTRAN program for Detrended Correspondence Analyses and Reciprocal Averaging. Cornell University, Ithaca, New York, U.S.A. : 95 p.

Imbert J.B. \& Pozo J. 1989. - Breakdown of four leaf litter species in a Basque Country forested stream. Hydrobiologia, $182: 1-14$.

Iversen T.M. 1973. - Decomposition of autumn-shed beech leaves in a springbrook and its significance for the fauna. Arch. Hydrobiol., 72 : 305-312.

Iversen T.M. 1988. - Secondary production and trophic relationships in a spring invertebrate community. Limnol. Oceanogr., 33 : 582-592.

Jorgensen S.E. 1980. - Lake Management. Pergamon Press, Oxford, U.K. : 167 p.

McArthur J.V., Barnes J.R. \& Hansen B.J. 1988. - Seasonal dynamics of leaf litter breakdown in a Utah Alpine stream. J.N. Am. Benthol. Soc., $7: 44-50$.

McGeorge J.E., Jagoe C.H., Risley L.S. \& Morgan M.D. 1991. Litter decomposition in low $\mathrm{pH}$ streams in the New Jersey Pinelands. Verh. internat. Ver. Limnol., 24 : 1711-1714.

Merritt R.W. \& Cummins K.W. 1984. - An Introduction to the Aquatic Insects of North America. $2^{\text {nd }}$ ed. Kendall/Hunt, Dubuque, Iowa, U.S.A. : 722 p.

Merritt R.W. \& Lawson D.L. 1992. - The role of leaf litter macroinvertebrates in stream-floodplain dynamics. Hydrobiologia, $248: 65-72$.

Minshall G.W. 1966. - Role of allochtonous detritus in the trophic structure of a woodland springbrook community. Eco$\log y, 48: 710$.

Minshall G.W., Petersen R.C., Cushing C.E., Cummins K.W., Bott T.L., Sedell J.R. \& Vannote R.L. 1983. - Interbiome comparison of stream dynamics. Ecological Monograph., 1 : 1-25.

Minshall G.W., Petersen R.C., Bott T.L., Cushing C.E., Cummins K.W., Vannote R.L. \& Sedell J.R. 1992. - Stream ecosystem dynamics of the Salmon River, Idaho : an 8th-order system. J.N. Am. Benthol. Soc., 11 : 111-137.

Naiman R.J. \& Sedell J.R. 1979. - Benthic organic matter as function of stream order in Oregon. Arch. Hydrobiol., 87 : 404-422. 
Newbold J.D., Elwood J.W., Schulze, M.S., Stark R.W. \& Barmeier J.C. 1983. - Continuous ammonium enrichment of a woodland stream : uptake kinetics, leaf decomposition and nitrification. Freshwat. Biol., 13 : 193-204.

Novozamski I., Houba V., van Eck R. \& van Wark 1983. - A novel digestion technique for multi-element plant analysis. Communications in Soil Science and Plant Analysis, 14 : 239-249.

Platts W.S., Armour C. \& Booth G.D. 1973. - Methods for evaluating riparian habitats with applications to management. Report INT-221, U.S.D.A. : 177 p.

Podani J. 1990. - SYN-TAX IV. International Centre for Science and Technology, UNIDO. Budapest, Hungary : $120 \mathrm{p}$.

Potts D.F. \& Anderson B.K.M. 1990. - Organic debris and the management of small stream channels. Western J, applied Forestry, $5: 25-28$

Pozo J. 1993. - Leaf litter processing of alder and eucalyptus in the Agüera stream system (North Spain). I - Chemical changes. Arch. Hydrobiol., 127 : 299-317.

Richardson J.S. 1992. — Food, microhabitat, or both ? Macroinvertebrate use of leaf accumulations in a mountain stream. Freshwat. Biol., 27 : 169-176.
Rounick. J.S. \& Winterbourn M.J. 1983. - Leaf processing in two contrasting beech forest streams : effects of physical and biotic factors on litter breakdown. Arch. Hydrobiol., 96 : 448-474.

Statzner B. 1987. - Characteristics of lotic ecosystems and consequences for future research directions. Ecological Studies, $61: 365-390$.

Taylor B.R., Parkinson D. \& Parsons W.F.J. 1989. - Nitrogen and lignin content as predictors of litter decay rates : a microcosm test. Ecology, $70:$ 97-104.

Ter Braak C.J.F. 1987. - CANOCO. TNO-Institute of Applied Computer Science. Wageningen, The Netherlands : $82 \mathrm{p}$.

Thompson P.L. \& Bärlocher F. 1989. - Effect of pH on leaf breakdown in streams and in the laboratory. J.N. Am. Benthol. Soc., $8: 203-210$.

Vannote R.L., Minshall G.W., Cummins K.W., Sedell J.R. \& Cushing C.E. 1980. - The river continuum concept. Can. J. Fish. aquat. Sci., $37:$ 130-137.

Wetzel R.G. \& Likens G.E. 1991, - Limnological Analyses. $2^{\text {nd }}$ ed. Springer Verlag, New-York, U.S.A. : 391 p. 